\title{
POLA LUKA PADA KEKERASAN DALAM RUMAH TANGGA TERHADAP PEREMPUAN DI RS BHAYANGKARA MANADO PERIODE 2013
}

\author{
${ }^{1}$ Emmanuela R. Molenaar \\ ${ }^{2}$ Nola T. S. Mallo \\ ${ }^{2}$ Erwin G. Kristanto
}

\author{
${ }^{1}$ Kandidat Skripsi Fakultas Kedokteran Universitas Sam Ratulangi Manado \\ ${ }^{2}$ Bagian Ilmu Kedokteran Forensik dan Medikolegal Fakultas Kedokteran \\ Universitas Sam Ratulangi Manado \\ Email: emolenaar11.002@gmail.com
}

\begin{abstract}
Violence in a family shows a tendency to increase every year. Studies from other countries showed that the occurance of this violance was about $15-17 \%$. Most of the victims are adult females and the culprits are mostly the husbands. There are several methods needed to detect such cases. Doctors and their medical staff must have the ability to identify the condition of the victim inlcuding psychological and physical condition as well as the types of wounds. Theis study aimed to obtain the pattern of wound types in female victims related to violence in family. This was a retrospective and descriptive study using reports of visum et repertum of Bhayangkara Hospital Manado as the secondary data. The results showed that of the 43 cases, the majority belonged to the group of age 31-32 years old (10 people), physical type of violance (93\%), bruise as the type of wound (70\%), and located at the forehead and the back part of the head (18.60\%).
\end{abstract}

Keywords: Violence, family, type of injury

\begin{abstract}
Abstrak: Kekerasan dalam rumah tangga (KDRT) merupakan salah satu kasus yang terus meningkat dari tahun ke tahun. Studi dari berbagai negara menunjukkan angka kejadian KDRT berkisar antara 15-71\%. Sebagian besar korban KDRT ialah perempuan dewasa dan pelaku biasanya ialah suami. Dalam pengungkapan kasus KDRT diperlukan metode-metode tertentu dari dokter atau tenaga kesehatan untuk mendektesinya. Dokter atau tenaga medis harus mampu mengetahui keadaan psikologis dan fisik, serta pola luka/cedera yang dialami korban. Penelitian ini bertujuan untuk mengetahui dan meningkatkan kemampuan deteksi kasus KDRT terhadap perempuan bagi para dokter melalui pola luka. Penelitian ini bersifat deskriptif retrospektif dengan menggunakan data sekunder dari hasil visum dan dilaporkan menurut distribusi frekuensi. Hasil penelitian menunjukkan bahwa dari 43 kasus KDRT terhadap perempuan terbanyak ialah kelompok umur 31-32 tahun (10 orang), jenis kekerasan fisik (93\%), jenis cedera memar (70\%), letak cdera daerah sekitar dahi dan kepala bagian belakang (18,60\%).
\end{abstract}

Kata kunci: kekerasan dalam rumah tangga, pola cedera

Kekerasan dalam rumah tangga (KDRT) merupakan salah satu kasus yang terus meningkat dari tahun ke tahun. Kekerasan dalam rumah tangga merupakan hal yang universal dan dapat terjadi tanpa memandang usia, profesi, tingkat ekonomi maupun pendidikan dari individu yang mengalaminya. Sebagian besar korban KDRT adalah perempuan dewasa dan pelakunya biasanya ialah suami. 
Di provinsi Sulawesi Utara, jumlah kasus yang masuk di bagian Pengaduan Masyarakat pada tahun 2010 sebanyak 57 kasus dan pada tahun 2011 mengalami peningkatan sebesar 359, 65\% menjadi 262 kasus. Sepanjang tahun 2011, Bagian Pengaduan Masyarakat pada Biro Hukum dan Humas Kementerian Pemberdayaan Perempuan dan Perlindungan Anak telah menerima pengaduan kasus mulai bulan Januari 2011 sampai Desember 2011 sebanyak 262 pengaduan. ${ }^{1}$

Dalam pengungkapan kasus KDRT, diperlukan metode-metode tertentu dari dokter atau tenaga kesehatan untuk mendektesinya. Dalam hal ini, aspek-aspek dari forensik klinik sangat berperan. Dokter atau tenaga medis harus mampu mengetahui keadaan psikologis dan keadaan fisik, didalamnya pola luka/cedera yang dialami korban, apakah murni karena tindak kekerasan yang dilakukan terhadap korban atau karena hal yang lain. ${ }^{2}$

Traumatologi Forensik adalah suatu bagian ilmu kedokteran, khususnya tentang trauma fisik, yang mempelajari derajat keparahan luka/cedera, hubungan luka/cedera dengan kekerasan penyebabnya serta kaitannya dengan hukum. Sedangkan setiap bentuk kekerasan yang menyebabkan luka pada seseorang dari segi mediko-legal, yang disebut dengan istilah cedera. Suatu keadaan dimana terputusnya kontinuitas jaringan tubuh disebut juga dengan istilah luka.

Peranan tenaga kedokteran forensik terhadap KDRT merupakan sarana bagi para korban untuk mendapatkan hak mereka yaitu keadilan. Peranan dokter forensik dalam kekerasan ialah untuk mengetahui dan menyelidiki tanda-tanda kekerasan sesuai fungsi dokter forensik di lapangan menurut UU No.23 tahun 2004. ${ }^{3}$

\section{METODE PENELITIAN}

Penelitian yang dilakukan bersifat deskriptif retrospektif dengan menggunakan data sekunder dari hasil visum yang tercatat di RS Bhayangkara Manado periode tahun 2013. Sampel penelitian yaitu semua kasus KDRT terhadap perempuan. Variabel penelitian yaitu jumlah kasus, jenis kelamin, umur, jenis kekerasan, pola cedera, dan letak cedera.

\section{HASIL PENELITIAN DAN BAHASAN}

Berdasarkan penelitian yang dilakukan di RS Bhayangkara Manado periode 2013 maka diperoleh data berdasarkan variabel sebagai berikut:

Tabel.1 Jenis kekerasan pada kasus dengan dugaan KDRT terhadap perempuan di RS Bhayangkara Manado periode 2013.

\begin{tabular}{lc}
\hline \multicolumn{1}{c}{ Jenis kekerasan } & $\begin{array}{c}\text { Jumlah } \\
\text { kasus }\end{array}$ \\
\hline Kekerasan Fisik & 40 \\
Kekerasan Seksual & 2 \\
$\begin{array}{l}\text { Kekerasan Fisik disertai } \\
\text { kekerasan seksual }\end{array}$ & 1 \\
\hline Jumlah & $\mathbf{4 3}$ \\
\hline
\end{tabular}

Data di RS Bhayangkara Manado tahun 2013 menunjukkan presentase jenis kekerasan dalam rumah tangga yang terjadi ialah kekerasan fisik (93\%), kekerasan seksual (5\%), dan kekerasan fisik disertai kekerasan seksual (2\%). Hal ini menunjukkan bahwa korban yang mengalami kekerasan dalam kasus KDRT di kota Manado sebagian besar mengalami tindak kekerasan secara fisik. Penyebab kekerasan fisik yang terjadi pada kasus KDRT kemungkinan karena saat kejadian berlangsung, pelaku sedang mengalami tekanan atau dibawah pengaruh alkohol sehingga hilang kendali dan kemudian dengan mudah menggunakan kekuatan fisik.

Kecenderungan tindak KDRT juga bisa terjadi karena faktor dukungan sosial dan budaya dimana perempuan ditempatkan pada posisi yang lebih rendah dari lakilaki sehingga kekerasan seringkali digunakan dan dianggap sebagai hal yang wajar. $^{4,5}$ Adapun faktor lain yang menyebabkan terjadinya KDRT terhadap perempuan yang dilakukan oleh suami terhadap istri, yaitu kekerasan digunakan sebagai alat untuk menyelesaikan konflik., 
Tabel 2. Jumlah kasus menurut jumlah cedera dan lokasi cedera berdasarkan data di RS Bhayangkara

\begin{tabular}{cc}
\hline Variabel & Jumlah kasus (\%) \\
\hline Jumlah cedera & $\mathbf{2 0}(\mathbf{4 6 , 5 1 \% )}$ \\
1 jenis cedera & $\mathbf{2 3 ( 5 3 , 4 9 \% )}$ \\
$>$ 1 jenis cedera & \\
\hline Jumlah lokasi cedera & $\mathbf{1 5}(\mathbf{3 4 , 8 8 \% )}$ \\
1 lokasi & $\mathbf{2 8 ( 6 5 , 1 2 \% )}$ \\
$>$ 1 lokasi & \\
\hline
\end{tabular}

Hal ini menunjukkan bahwa lebih dari separuh korban Kekerasan Dalam Rumah Tangga mengalami kekerasan yang berulang-ulang sehingga mengalami cedera di beberapa letak yang berbeda.

Tabel 3. Jenis cedera pada kasus KDRT di RS Bhayangkara Manado

\begin{tabular}{lcc}
\hline \multicolumn{1}{c}{ Jenis cedera } & Jumlah & \\
kasus & $\%$ \\
\hline Robekan selaput dara & 3 & 4,11 \\
Memar & 29 & 69,86 \\
Luka (lecet dan gores) & 19 & 26,03 \\
\hline
\end{tabular}

Berdasarkan hasil penelitian yang diperoleh melalui data di RS Bhayangkara Manado, dari keseluruhan cedera yang terjadi didapatkan jenis cedera yang terjadi adalah memar sebesar 69,86\%, luka (luka lecet dan luka gores) sebesar 26,03\%, dan robekan selaput dara sebesar $4,11 \%$. Hal ini menunjukkan bahwa jenis cedera yang paling sering terjadi ialah memar $(69,86 \%)$. Hal ini terjadi karena sebagian besar pelaku KDRT melakukan tindak kekerasan dengan tujuan ingin memberikan pelajaran dan bukan untuk membuat luka yang mematikan. $^{8,9}$

Pada pemeriksaan dalam, ditemukan jenis cedera robekan selaput dara (hymen) yang terjadi ialah robekan lama. Korban yang mengalami cedera robekan selaput dara ialah korban yang mengalami kekerasan seksual. Kekerasan seksual yang dimaksud adalah setiap penyerangan yang bersifat seksual terhadap perempuan, baik telah terjadi persetubuhan atau tidak, dan tanpa memperdulikan hubungan antara pelaku dengan korban. ${ }^{10}$

Pada pemeriksaan fisik didapatkan adanya luka memar, gores, dan lecet. Luka memar adalah suatu perdarahan akibat pecahnya pembuluh darah kapiler dan vena dalam jaringan bawah kulit atau kutis yang disebabkan oleh kekerasan benda tumpul, perdarahan yang terjadi menyebabkan darah meresap ke jaringan sekitarnya. ${ }^{11}$ Pada jenis cedera luka yang terjadi didapatkan 2 jenis luka yaitu luka lecet (79\%) dan luka gores (21\%). Luka lecet terjadi akibat cedera pada epidermis yang bersentuhan dengan benda yang memiliki permukaan kasar atau runcing. Manfaat interpretasi luka lecet ditinjau dari aspek medikolegal seringkali diremehkan, padahal pemeriksaan luka lecet yang teliti dapat mengungkapkan peristiwa yang sebenarnya terjadi. Luka gores diakibatkan oleh benda runcing (misalnya kuku jari yang menggores kulit) yang menggeser lapisan tersebut terangkat sehingga dapat menunjukaan arah kekerasan yang terjadi. ${ }^{12}$ Pada kasus KDRT luka lecet dan gores yang terjadi dapat diakibatkan oleh goresan kuku dari pelaku atau terjadi akibat benda tumpul yang digunakan pelaku saat melakukan kekerasan terhadap korban.

Gambar 1 dan 2 menunjukkan bahwa daerah yang paling sering mengalami cedera pada kasus KDRT berdasarkan data yang diperoleh di RS Bhayangkara Manado tahun 2013 ialah di bagian kepala belakang dan dahi. Hal ini terjadi karena pelaku kemungkinan melakukan pemukulan menggunakan tangan maupun alat seperti kayu atau parang dan mengenai kepala korban, atau bahkan membenturkan kepala korban ke tembok sehingga mengalami cedera di bagian kepala belakang dan dahi. 


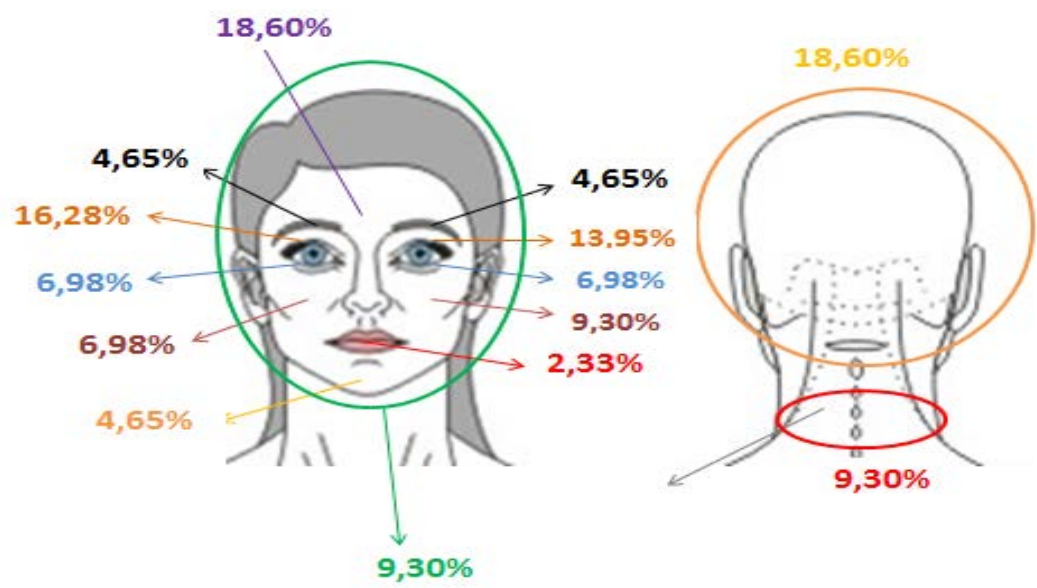

Gambar 1. Letak cedera pada korban kasus KDRT

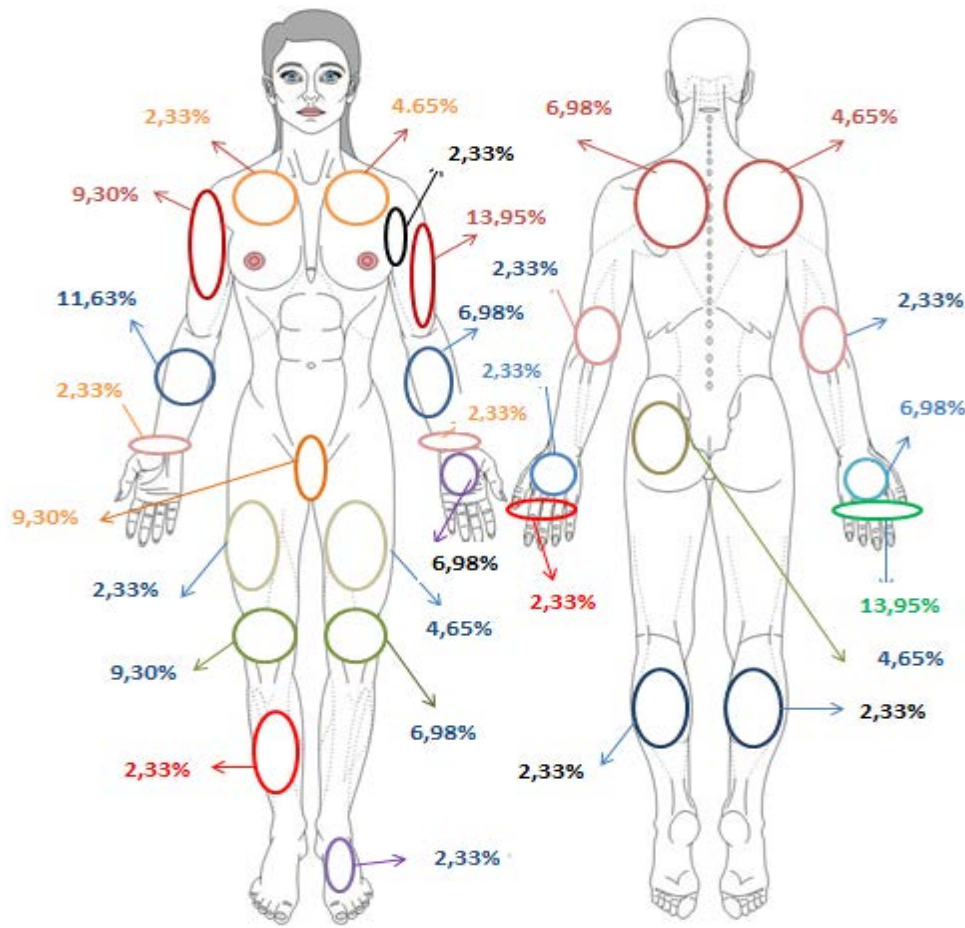

Gambar 2. Letak cedera pada korban kasus KDRT 
Tabel 4. Distribusi jumlah cedera berdasarkan lokasi pada kasus Kekerasan Dalam Rumah Tangga terhadap perempuan berdasarkan data di RS Bhayangkara Manado

\begin{tabular}{|c|c|}
\hline Letak cedera & Jumlah cedera \\
\hline - Dahi & 8 \\
\hline - $\quad$ Kepala belakang & 8 \\
\hline - Kepala depan & 4 \\
\hline - $\quad$ Mata kanan & 7 \\
\hline - $\quad$ Mata kanan bawah & 3 \\
\hline - $\quad$ Mata kiri atas & 6 \\
\hline - $\quad$ Mata kiri bawah & 3 \\
\hline - $\quad$ Pipi kanan & 3 \\
\hline - $\quad$ Pipi kiri & 4 \\
\hline - $\quad$ Alis kanan & 2 \\
\hline - $\quad$ Alis kiri & 2 \\
\hline - $\quad$ Bibir & 1 \\
\hline - $\quad$ Leher & 4 \\
\hline - Dagu & 2 \\
\hline - Dada kanan & 1 \\
\hline - $\quad$ Dada kiri & 2 \\
\hline - $\quad$ Axila kiri & 1 \\
\hline - $\quad$ Punggung belakang kanan & 2 \\
\hline - $\quad$ Punggung belakang kiri & 3 \\
\hline - $\quad$ Telapak tangan kiri & 3 \\
\hline - $\quad$ Punggung tangan kanan & 3 \\
\hline - $\quad$ Punggung tangan kiri & 1 \\
\hline - $\quad$ Pergelangan tangan kanan & 1 \\
\hline - $\quad$ Pergelangan tangan kiri & 1 \\
\hline - Jari-jari kiri & 1 \\
\hline - Jari-jari kanan & 6 \\
\hline - $\quad$ Lengan kanan atas & 4 \\
\hline - $\quad$ Lengan kanan bawah & 5 \\
\hline - $\quad$ Lengan kiri atas & 6 \\
\hline - $\quad$ Lengan kiri bawah & 3 \\
\hline - $\quad$ Lipatan siku kanan & 1 \\
\hline - $\quad$ Lipatan siku kiri & 1 \\
\hline - Paha kanan & 1 \\
\hline - $\quad$ Paha kiri & 2 \\
\hline - $\quad$ Lutut kanan & 4 \\
\hline - $\quad$ Lutut kiri & 3 \\
\hline - $\quad$ Betis kanan & 1 \\
\hline - $\quad$ Betis kiri & 1 \\
\hline - $\quad$ Bokong kiri & 2 \\
\hline - $\quad$ Tungkai kanan & 1 \\
\hline - $\quad$ Punggung kaki kiri & 1 \\
\hline - $\quad$ Selaput dara & 3 \\
\hline - $\quad$ Bibir vagina & 1 \\
\hline
\end{tabular}

\section{SIMPULAN}

Berdasarkan hasil penelitian mengenai pola luka pada KDRT terhadap perempuan di RS Bhayangkara Manado periode 2013 dapat disimpulkan sebagai berikut :
1. Jenis kekerasan yang sering terjadi ialah kekerasan fisik, kekerasan seksual, dan kekerasan fisik disertai kekerasan seksual dimana kasus kekerasan fisik yang tertinggi. 
2. Korban dengan usia produktif cukup banyak dengan usia terbanyak 31-32 tahun.

3. Korban yang mengalami KDRT sebagian besar mengalami kekerasan yang berulang.

4. Jenis cedera yang paling sering terjadi pada korban kasus KDRT terhadap perempuan ialah memar.

5. Letak cedera yang tersering terjadi yaitu di bagian kepala belakang dan dahi.

\section{SARAN}

1. Edukasi tentang pentingnya tindakan untuk melaporkan sedini mungkin pada kasus KDRT.

2. Para dokter membantu petugas kepolisian agar dapat mendeteksi korban yang mengalami kasus KDRT.

3. Meningkatkan dan memperhatikan dengan teliti tentang kasus KDRT melalui pola cedera yang terjadi.

\section{DAFTAR PUSTAKA}

1. Laporan Pelayanan Pengaduan Masyarakat tahun 2011.

2. Satyo AC. Aspek medikolegal luka pada forensik klinik. Majalah Kedokteran Nusantara. 2006;39(4): 430-2.

3. Idries AM, Tjiptomartono AL. Penerapan Ilmu Kedokteran Forensik dalam Proses Penyidikan. Jakarta: Sagung Seto, 2009.
4. Heise LL, Pitanguy J, Germain A. Violence against Women: The Hidden Health Burden. Washington: World Bank, 1994.

5. Faktor penyebab KDRT (Internet). 2013. [cited 2014 Dec 10]. Available from: Health.detik.com

6. Purwoko A, Sukiyono K, Priyono BS. Probabilitas terjadinya tindak kekerasan terhadap wanita dalam rumah tangga: Studi pada masyarakat berbasis pertanian di Kabupaten Bengkulu Utara. Sosiohumoniora. 2011;13(1):58-75.

7. Istiadah. Pembagian Kerja Rumah Tangga dalam Islam. Jakarta: Lembaga Kajian Agama dan Jender dengan PSP.

8. Baker RB, Sommers MS. Physical injury from intimate partner violonce: measurement strategies and challenges. JOGNN. 2008;37:228-33.

9. Sheridan DJ, Nash KR. Acute injury patterns of intimate partner violence victims. Trauma Violence Abuse. 2007;8:281-9.

10.Sampurna B, Samsu Z, Siswaja TD. Peranan Ilmu Forensik dalam Penegakan Hukum, 2008

11.Price SA, Wilson LM. Patofisiologi: Konsep Klinis Proses-Proses Penyakit. EGC: Jakarta, 1994.

12.Budiyanto A, Widiatmaka W, Sudiono S, Mun'im TWA, Sidhi, Hertian S, et al. Ilmu Kedokteran Forensik. Jakarta: Bagian Kdokteran Forensik FKUI, 1997. 